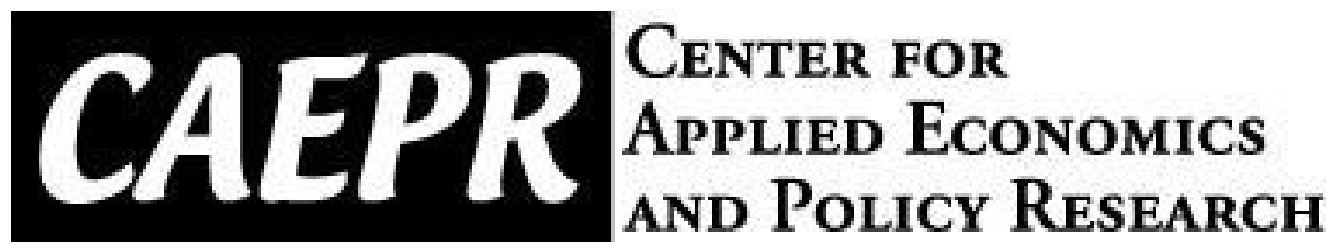

CAEPR Working Paper

\#2015-020

\title{
Positive and Negative Effects of Financial Development on Export Prices
}

\author{
ByeongHwa Choi \\ Indiana University
}

\section{Volodymyr Lugovskyy \\ Indiana University}

October 1, 2015

This paper can be downloaded without charge from the Social Science Research Network electronic library at http://papers.ssrn.com/sol3/papers.cfm?abstract_id=2698243

The Center for Applied Economics and Policy Research resides in the Department of Economics at Indiana University Bloomington. CAEPR can be found on the Internet at:

http://www.indiana.edu/ caepr. CAEPR can be reached via email at caepr@indiana.edu or via phone at 812-855-4050.

(C)2015 by ByeongHwa Choi and Volodymyr Lugouskyy. All rights reserved. Short sections of text, not to exceed two paragraphs, may be quoted without explicit permission provided that full credit, including (c) notice, is given to the source. 


\title{
Positive And Negative Effects of Financial Development on
}

\author{
EXPORT PRICES *
}

\author{
ByeongHwa Choi ${ }^{\dagger} \quad$ Volodymyr Lugovskyy ${ }^{\ddagger}$
}

October 1, 2015

\begin{abstract}
We present a model of international trade in which credit constrained firms endogenously choose quality and countries differ in their level of financial development. This model produces a novel result where the total effect of financial development on export prices exhibits a U-shaped relationship with the exporter's labor productivity. The effect is positive for countries with the lowest and highest levels of productivity and negative for the countries in the middle. This occurs because financial development has two opposing effects on export prices: it reduces the costs of production while enabling costly quality upgrading. We confirm this pattern using a sample of U.S. imports from all exporters worldwide. This finding suggests that financial development has different implications for countries with different levels of productivity and income.
\end{abstract}

JEL classification: F10, F14, G20, J24, O14

Keywords: Financial development, Quality, Export prices, Labor productivity

\footnotetext{
${ }^{*}$ We thank Adina Ardelean, Tibor Besedeš, and Alexandre Skiba for helpful comments and suggestions.

${ }^{\dagger}$ Department of Economics, Indiana University, 105 Wylie Hall, 100 S. Woodlawn Avenue, Bloomington, IN 47405, U.S.A.; byechoi@indiana.edu

$\ddagger$ Assistant Professor of Economics, Indiana University, 105 Wylie Hall, 100 S. Woodlawn Avenue, Bloomington, IN 47405, U.S.A.; vlugovsk@indiana.edu
} 


\section{INTRODUCTION}

A country's ability to export is vital for its economic growth and development. ${ }^{1}$ A growing number of empirical studies are documenting the importance of financial development for reducing firms' borrowing costs (e.g., Beck, 2002, 2003; Manova, 2013; Svaleryd and Vlachos, 2005) and inducing quality upgrading (e.g., Fan et al., 2015) to enable the firms to become more successful exporters. ${ }^{2}$ However, these studies present mixed evidence on how financial development affects export prices. For example, Phillips and Sertsios (2013) argue that less financially constrained firms produce higher quality products and therefore charge a higher price. Fan et al. (2015) predict theoretically and confirm empirically that the qualityadjustment effect dominates the cost-adjustment effect, and thus the firms that have easier access to credit face an increase in export prices. Furthermore, Secchi et al. (2014) show that financially constrained Italian exporters charge higher prices than unconstrained firms within the same product-destination market, while this effect is weaker for vertically differentiated products.

The aim of this paper is to further clarify how financial development affects export prices. We show theoretically and confirm empirically that there is a U-shaped relationship between the effect of financial development on export prices and labor productivity. Empirically, we confirm this U-shaped relationship using the U.S. imports product-level data for the years 1991-2007. We find that the effect is negative for the vast majority of countries with the magnitude varying between a 0 and $2.7 \%$ decrease in prices due to a $10 \%$ increase in the measure of financial development (the ratio of private credit to GDP). The effect is positive only for up to $7 \%$ of exporters to the U.S., with the corresponding magnitude varying between 0 and $1.8 \%$.

Theoretically, we consider the endogenous quality choice (with the production function

\footnotetext{
1 The bulk of empirical studies, including Balassa (1978), Feder (1983), Kavoussi (1984), Krueger (1980), and Moschos (1989), support this view. Export growth increases capacity utilization and results in greater economies of scale (Balassa, 1978; Krueger, 1980).

${ }^{2}$ In addition to the lower cost factor, studies show that quality upgrading is essential for successful exporting, especially for developing countries (see, e.g., Brooks, 2006; Iacovone and Javorcik, 2008; Verhoogen, 2008).
} 
as in Verhoogen, 2008) of financially constrained exporters. As in Verhoogen (2008), we use a partial-equilibrium model, where the wages in the industry of interest are determined by the rest of the economy. We assume that wages increase linearly in the efficient units of labor per worker (which we refer to as labor productivity) and show that the effect of financial development on prices first decreases and then increases in the labor productivity.

Intuitively, our theoretical predictions emerge from the interplay between the decreasing marginal product of labor productivity in quality upgrading and the linear relationship between labor productivity and wages. Thus, quality upgrading is relatively cheap for firms in countries with very low levels of labor productivity, but it becomes increasingly expensive as labor productivity increases. As a result, a lower cost of credit provides a strong incentive for firms in countries with the lowest levels of labor productivity to upgrade their quality, since the wages are relatively low compared to the marginal product of labor in the quality production. Examples are Bangladesh, famous for its high-quality woven cottons and silks, and Ethiopia, producing high-quality coffee which has a price premium. For the firms in these countries, the quality-adjustment effect is likely to be stronger than, or of comparable magnitude to, the cost-adjustment effect. As labor productivity increases, however, the incentive to upgrade quality due to the lower cost of credit decreases, and thus the qualityadjustment effect becomes relatively weaker than the cost-adjustment effect in countries with medium levels of labor productivity. Finally, in countries with high productivity, the initial quality and wages are already high. Consequently, the firms in these countries face very high costs even when they allow for incremental increases in quality, making the qualityadjustment effect stronger than the cost-adjustment effect.

We provide empirical support for our predictions using the highly disaggregated productlevel data on U.S. imports for 1991-2007. On average, financial development tends to reduce the export free-on-board (f.o.b.) price. Further, the price of differentiated goods is estimated to decrease typically by $2.4 \%$ for every $10 \%$ increase in the private-credit-to-GDP ratio. Importantly, we show that a U-shaped relationship exists between the effect of financial 
development on prices and the income per capita of exporting countries. ${ }^{3}$ For the vast majority of countries, we find that financial development has a negative effect on export prices and a positive effect, depending on the year, for only about $5-7 \%$ of the countries. At the same time, we observe a substantial variation in the magnitudes of the negative effects of financial development on prices both across time and country. We observe the strongest negative effect for the middle-income countries, where the income per capita is around $\$ 3,563$, which translates to a $2.7 \%$ decrease in export prices for every $10 \%$ increase in the private credit-to-GDP ratio. Further, we observe the weakest negative effect-a $0-0.5 \%$ decrease in export prices for every $10 \%$ increase in financial development-for low-income countries with a per capita income between $\$ 241$ and $\$ 314$, and for rich countries with a per capita income between $\$ 40,403$ and $\$ 52,414$. We also predict that with income growth, the effect of financial development on export prices will tend to be more negative for countries with a per capita income below $\$ 3,506$ (58\% of countries between 1991 and 2007) per year and less negative for countries with a per capita income above $\$ 3,506$.

Our results are robust to the exclusion of countries neighboring the U.S. (i.e., Canada and Mexico) due to low transport costs, and to the exclusion of the largest developing countries with low labor costs (i.e., China and India). In the industry-specific analysis, we observe a U-shaped relationship between the effect of financial development on export prices and income in 9 out of 15 industries, accounting for $69 \%$ of the total export value.

This paper contributes to several important literature streams. First, we extend the growing empirical literature documenting the systematic variation in the impact of financial development on export performance, by yielding different policy implications. For instance, Manova (2013) argues that financially developed countries are likely to participate in the export market, export a large variety of products, and have high export values, and these effects are most pronounced in sectors that require relatively high external finance and that have few collateralizable assets. Furthermore, Berthou (2010) finds a hump-shaped relationship

\footnotetext{
3 The coefficient estimates of the interaction between financial development and GDP per capita are negative and statistically significant, and the estimates of the interaction between financial development and the quadratic term of per capita income have significantly positive signs.
} 
between the marginal effect of financial development on exports and the initial development of financial institutions. Since developed and developing countries differ substantially in terms of labor productivity and economic systems, this paper attempts to provide different implications of financial development for countries of differing income levels by focusing on the variation across countries, rather than across sectors.

Second, we contribute to the literature on the vertical differentiation in international trade and the factors that increase export prices. Flam and Helpman (1987) and Fajgelbaum et al. (2011) show theoretically, while Schott (2004) and Hummels and Klenow (2005) confirm empirically, that richer countries export higher-priced goods and focus on quality differentiation as a source of comparative advantage. While many factors may influence export prices, numerous studies demonstrate that a positive correlation exists between product quality and prices, including those of Bils and Klenow (2001), Verhoogen (2008), Baldwin and Harrigan (2011), Crozet et al. (2012), Manova and Zhang (2012), and Antoniades (2015). In this paper, we show that financial constraints represent another important determinant of the variation in product quality and prices. The positive correlation between product quality and financial development is relatively well-documented (Ciani and Bartoli, 2014; Fan et al., 2015). We contribute to this literature stream by showing that prices tend to decrease with financial development even in the presence of quality differentiation. To the best of out knowledge, Secchi et al. (2014) are the only ones to find that firms facing tight credit constraints charge higher export prices where quality-adjustment and cost-adjustment effects coexist. ${ }^{4}$ The novel contribution of our paper is that it identifies the non-monotonic effects of financial development, which depend on a country's labor productivity.

The remainder of the paper is organized as follows. Section 2 presents the theoretical model featuring vertical product differentiation and credit constraints to illustrate the impact of financial development on export prices. It also accounts for the non-linear effect of financial development on prices across countries with different levels of labor productivity. Section 3 outlines the data and the strategy of the empirical analysis. Section 4 provides empirical

\footnotetext{
${ }^{4}$ Secchi et al. (2014) focus on Italian manufacturing firms during the period 2000-2003 and do not have theoretical support.
} 
support for the model using product-level U.S. import data. Section 5 concludes the paper.

\section{MOdel}

We build on Verhoogen's (2008) model focusing on the quality-upgrading process and designed to provide predictions that match the empirical evidence documented in the literature. We consider the model from the perspective of one country, Importer, which imports from multiple exporters. We show that the quality of a good shipped from a source country to a destination country can be influenced by the demand from other countries. To do this, we model the quality choice of monopolistically competitive firms in a given country facing demands from $i=1,2, \ldots, I$ countries including the country of origin.

Within a given country, all firms have access to the same technology and resources, and thus they are symmetric in the equilibrium. An important extension that we make to Verhoogen's (2008) model is as follows: we consider that wages and country-specific entrepreneurial skills increase in labor productivity and are not exogenously given but are (increasing) functions of the labor productivity level in a given country. This is a standard assumption in most labor search models (see, e.g., Altonji and Blank, 1999; Haltiwanger et al., 2007; Jovanovic, 1984; Moscarini, 2005; Pissarides, 1990; Rogerson et al., 2005). The model is partial-equilibrium, focused on a single industry that is small relative to the economy as a whole.

2.1 Demand In Importer, there is a mass $N_{I}$ of statistically identical consumers, each of whom is assumed to buy one unit of a good from a continuum of goods indexed by $\omega$. The indirect utility function is given by

$$
V(\omega)=\theta q(\omega)-\tilde{p}_{I}+\varepsilon, \quad \theta>0
$$

where $q$ is product quality, $\tilde{p}_{I}$ is the price of $\omega$ relative to the price level in Importer, $\theta$ is the consumers' willingness to pay for quality, and $\varepsilon$ is the random consumer-product match term, which is independent and identically distributed across consumers with a type 
1 extreme value distribution.

Let $\delta_{d}$ be the ratio of the price level in country $d$ relative to the price level in Importer. The price of good $\omega^{\prime}$ relative to the Importer's price level is then $p_{d}\left(\omega^{\prime}\right)=\delta_{d} \tilde{p}_{I}\left(\omega^{\prime}\right)$. The demand for good $\omega^{\prime}$ imported by Importer from country $d$ is then given by

$$
x_{I d}\left(\omega^{\prime}\right)=\frac{N_{I} \exp \left[\frac{1}{\mu}\left(\theta q_{d}\left(\omega^{\prime}\right)-\frac{p_{d}\left(\omega^{\prime}\right)}{\delta_{d}}\right)\right]}{\int_{\Omega_{I}} \exp \left[\frac{1}{\mu}\left(\theta q(\omega)-\tilde{p}_{I}(\omega)\right)\right] d \omega},
$$

where $\mu$ is a parameter of the distribution of $\varepsilon$ that captures the degree of differentiation between goods and $\Omega_{I}$ is the set of goods available in Importer. As the firms are assumed to be risk-neutral, in what follows, the demand will be written without the expectation operator.

2.2 Production In each country, there is a continuum of potential entrepreneurs of mass 1 that are heterogeneous in the productivity parameter $\lambda$, which can be interpreted as entrepreneurial ability or technical know-how. Plants enter the domestic and export markets, producing on different production lines.

Each unit of output carries fixed factor requirements: one worker and one machine. ${ }^{5}$ Product quality is assumed to depend on the quality of the worker, the technical sophistication of the machine, and the ability of the entrepreneur, combined in Cobb-Douglas fashion:

$$
q_{d}\left(k_{d}, e_{d}, \lambda_{d}\right)=\lambda_{d}\left(k_{d}\right)^{\alpha^{k}}\left(e_{d}\right)^{\alpha^{l}}
$$

where $k_{d}$ represents the amount of capital embodied in the machine and $e_{d}$ represents the quality of the worker. Let $\alpha \equiv \alpha^{k}+\alpha^{l}$ and assume that $\alpha<1$. This will ensure an interior solution in the choice of product quality.

Plants face worker quality-wage schedules that are assumed to be upward-sloping and,

\footnotetext{
5 The results are robust to having two types of labor - skilled and unskilled - as long as the production function of quality has constant returns to scale and the wages of both types of workers are linear in labor productivity.
} 
in the interest of simplicity, linear:

$$
e_{d}=z\left(w_{d}-\underline{w}_{d}\right)
$$

where $w_{d}$ is the wage, and $z$ is a positive constant. The variable $\underline{w}_{d}$ represents the average wage in the outside labor market of country $d .{ }^{6}$ Importantly, contrary to Verhoogen (2008), we assume that the wage and country $d$ 's entrepreneurial ability, $\lambda_{d}$, are linear functions of country $d^{\prime}$ s labor productivity, $u_{d}$ :

$$
\underline{w}_{d}=\gamma_{0}+\gamma_{1} u_{d} \quad \lambda_{d}=\gamma_{0}^{\lambda}+\gamma_{1}^{\lambda} u_{d}
$$

Each plant bears a fixed cost for entering its domestic market and an additional fixed cost for entering the export market. The combination of the constant marginal cost and fixed cost of entry generates increasing returns to scale. There is no cost to differentiation, and plants are constrained to offer only one variety. As a consequence, all plants differentiate and have a monopoly in the market for their particular variety.

2.3 Financial Constraints Firms face interest rate $r$ to cover their expenditures on labor - so effectively they pay labor $(1+r) w$ and they rent capital at the same cost $1+r$. The parameter for financial development is $\rho$ such that the interest rate, $r(\rho)$, is a decreasing function of the level of financial development. ${ }^{7}$

\footnotetext{
${ }^{6}$ It is taken to be exogenous in Verhoogen (2008).

${ }^{7}$ This idea is consistent with Galor and Zeira (1993), showing that stronger financial institutions imply lower enforcement costs and a lower interest rate.
} 
2.4 Equilibrium And Predictions Following Verhoogen (2008) (see equations (5a) and (5e), p.502 $)^{8}$, the equilibrium quality and price can be derived as follows:

$$
\begin{aligned}
& q^{*}=\left(\eta \lambda \delta_{d}^{\alpha} \theta^{\alpha}\right)^{1 /(1-\alpha)} \\
& p^{*}=\mu \delta_{d}+(1+r) \underline{w}+\alpha \delta_{d} \theta\left(\eta \lambda \delta_{d}^{\alpha} \theta^{\alpha}\right)^{1 /(1-\alpha)}
\end{aligned}
$$

where $\eta \equiv\left(z \alpha^{l}\right)^{\alpha^{l}}\left(\alpha^{k} /(1+r)\right)^{\alpha^{k}}$.

\subsection{Theoretical Predictions}

Proposition 1. Ceteris paribus, easier access to external finance increases export quality (quality-adjustment effect):

$$
\frac{\partial q}{\partial \rho}>0
$$

Proof. See Appendix A.

Proposition 2. Ceteris paribus, easier access to external finance decreases the production cost and corresponding export price for any given quality level $q^{\prime}$ (cost-adjustment effect):

$$
\frac{\partial p\left(q^{\prime}\right)}{\partial \rho}<0
$$

Proof. See Appendix A.

Proposition 3. In equilibrium, the quality-adjustment effect is stronger for countries with the lowest and the highest levels of labor productivity, while the cost-adjustment effect is stronger for countries with medium labor productivity. Thus, there is a non-monotonic relationship between the effect of easier access to credit on equilibrium price and labor productivity.

\section{Proof. See Appendix A.}

8 Since we add financial constraints, in equilibrium, the cost of labor increases from $\underline{w}$ to $(1+r) \underline{w}$ and firms borrow money to pay their export-oriented labor force. 
Since producing high quality goods requires investments in R\&D, innovation, and marketing, easier access to external financing helps firms finance these investments and increase output quality. At the same time, financial development reduces the cost of capital, and hence a firm can charge a lower price. This implies that the development of the financial system decreases export prices when the cost-adjustment effect dominates the quality-adjustment effect.

The model predicts that the marginal effect of financial development is nonlinearly related to the level of labor productivity. The intuition is as follows. Due to the decreasing marginal product of labor productivity in quality upgrading and the linear relationship between labor productivity and wages, quality upgrading is relatively cheap for firms in countries with very low levels of labor productivity, but it becomes increasingly expensive as labor productivity increases. As a result, a lower cost of credit provides a strong incentive for firms in countries with the lowest labor productivity levels to upgrade their quality, since their wages are relatively low compared to the marginal product of labor in the quality production. For these firms, the quality-adjustment effect is likely to be stronger than, or of comparable magnitude to, the cost-adjustment effect. However, as labor productivity increases, the incentive to upgrade quality due to the lower cost of credit decreases, and thus the qualityadjustment effect becomes weaker than the cost-adjustment effect in countries with medium levels of labor productivity. Finally, in countries with the highest productivity, the initial quality is already high, as are the wages. As a result, firms in these countries face very high costs even when there is an incremental increase in quality, which makes the qualityadjustment effect stronger than the cost-adjustment effect.

\section{Empirical Strategy and Data}

This section details the estimation of the effect of financial development on the export prices of products to test whether the estimates exhibit a non-monotonic relationship across countries located at various levels of per capita income as predicted by the model. 
3.1 DATA The trade data used in this study are those published by the U.S. Census Bureau. This database reports country and customs district data for value, quantity, shipping weights, import charges, and duties on an annual basis, and the data are highly disaggregated at the product level (HS 10-digit level). We convert the HS code to a time-consistent code using the concordance table developed by Pierce and Schott (2012). The U.S. import prices received by the exporting countries, denoted as $p_{g, o, t}$, are unit prices, calculated as the ratio of import value to quantity of product $g$ in year $t$ from country $o$. Since the import data are extremely noisy, we trim the data by removing varieties with extreme unit prices that fall below the 5th percentile or above the 95th percentile within the industry (HS 2-digit level) each year. ${ }^{9}$ This restricts the unit price value within the range of $\$ 0.101$ to $\$ 3,458,271$.

In order to identify the Alchian-Allen effect that a per-unit transport cost increases the quality of exported products, we include the measure of import charges incurred by the goods in transit, as reported in the U.S. Census data. ${ }^{10}$ We also take into account the tariff rate, which is calculated as the value of duties collected relative to the dutiable value of imported goods. We merge them with the exporting country's data, including domestic credit to the private sector (\% of GDP), GDP per capita (current US\$) ${ }^{11}$, and population. The private credit-to-GDP ratio is computed by the World Bank using data from the International Monetary Fund's International Financial Statistics, and the GDP per capita and population data come from the World Bank. We use a country's GDP per capita as an indicator of labor productivity because highly productive countries tend to have a high GDP per capita. A practical advantage of using GDP per capita is that it is available for most countries in the world over long periods of time. ${ }^{12}$

\footnotetext{
9 This is a data trimming technique used by Khandelwal (2010).

10 More specifically, the U.S. Census defines import charges as "... the aggregate cost of all freight, insurance, and other charges (excluding U.S. import duties) incurred in bringing the merchandise from alongside the carrier at the port of exportation-in the country of exportation-and placing it alongside the carrier at the first port of entry in the United States."

This study does not consider differences in the port of entry and associated costs.

11 The data reported in current prices for each year are in the value of the currency for that particular year.

12 Other papers that use GDP per capita as a measure of labor productivity (or human capital quality) include Akbari (1996) and Coulombe et al. (2014).
} 
Rauch (1999) classifies products according to whether they are (a) traded in an "organized exchange," and therefore treated as "homogeneous"; (b) not traded in an organized exchange, but having some quoted "reference price"; and (c) not having any quoted price, and thus treated as "differentiated." For consistency with our theoretical model, we limit the analysis to "differentiated" products.

3.2 Estimation Strategy In order to estimate the effect of financial development on export price, we run the following regression:

$$
\begin{aligned}
\ln p_{g, o, t}= & \beta_{0}+\beta_{1} \text { FinDev }_{o, t}+\beta_{2}\left(\text { FinDev }_{o, t} \cdot \ln y_{o, t}\right)+\beta_{3}\left(\text { FinDev }_{o, t} \cdot\left(\ln y_{o, t}\right)^{2}\right) \\
& +\beta_{4} \ln y_{o, t}+\beta_{5}\left(\ln y_{o, t}\right)^{2}+\gamma X+\mathbf{u}+\varepsilon_{g, o, t}
\end{aligned}
$$

The regressions are estimated using ordinary least squares (OLS). The dependent variable is the natural logarithm of the price of exported product $g$ from country $o$ in year $t$. FinDev $v_{o, t}$ is the measure of the financial development of the exporting country $o$ in year $t$, which is measured by the average private credit granted by deposit banks and other financial institutions as a share of GDP; $\ln y_{o, t}$ is the natural logarithm of the per capita GDP of exporting country $o$ in year $t$. We also include its quadratic term to see if a non-monotonic relationship exists across countries at various levels of per capita income. $X$ is a set of other control variables, such as the natural logarithm of per-unit freight charges, the tariff rate, and the natural logarithm of population; $\mathbf{u}$ is a fixed effect term of product-year that allows us to control for omitted variables; and $\varepsilon$ is the error term that includes all unobserved factors that may affect the price of exports. In all regressions, standard errors are clustered at the exporter-product level. Our model predicts that $\beta_{1}>0, \beta_{2}<0$, and $\beta_{3}>0$. For the non-linear relationship to hold, we need $\beta_{2}<0$ and $\beta_{3}>0$, and for $-\beta_{2} /\left(2 \beta_{3}\right)$ to be in a proper range, so that the vertex of the parabola corresponds to the income per capita of the middle income countries. 


\section{Results}

This section reports the main results to support the theoretical predictions. Table 1 shows the effect of financial development on the export price in the period 1991-2007 using OLS with fixed effects. First, we observe that financial development, on average, tends to reduce the price of exported products. In column 1 of Table 1 , on average, the price of differentiated goods is estimated to decrease by $2.4 \%$ for every $10 \%$ increase in private credit to GDP. When we exclude Canada and Mexico from the list of trading partners (column 2), the price is, on average, estimated to decrease by $2 \%$ for every $10 \%$ increase in private credit to GDP. Furthermore, even after we drop China and India from the analysis (column 3), the decrease does not disappear.

More importantly, we find that the negative marginal effect of financial development on the export price can be mitigated in high and low income countries. In Table 1, the coefficient estimates of the interaction between financial development and per capita income are negative and statistically significant. The estimates of the interaction between financial development and the quadratic term of per capita income have significantly positive signs. ${ }^{13}$ In other words, per capita GDP has a non-monotonic relationship with the effect of improved financial constraints on the export price, implying that the magnitude of the effect tends to first diminish and then increase again as income levels increase. These results support our propositions and reveal a trend of the effect of financial development on export prices across countries with different income levels. Our results are robust if we exclude countries neighboring the U.S. and the largest developing countries (columns 2 and 3).

\footnotetext{
13 Centering to reduce multicollinearity does not change the results. This demonstrates that collinearity is not an issue; a large sample size could compensate for multicollinearity.
} 
Table 1: Estimated coefficients from OLS models of export price by financial development, 1991-2007

\begin{tabular}{lccc}
\hline \hline Dependent variable: $\ln ($ Unit price $)$ & & \\
& & Excluding Canada & Excluding China \\
and Mexico & $(1)$ & $(2)$ & $(3)$ \\
& $2.200^{* * *}$ & $2.506^{* * *}$ & $2.963^{* * *}$ \\
FD & $(0.128)$ & $(0.125)$ & $(0.180)$ \\
& $-0.604^{* * *}$ & $-0.633^{* * *}$ & $-0.748^{* * *}$ \\
FD $\times \ln y$ & $(0.029)$ & $(0.029)$ & $(0.040)$ \\
& $0.037^{* * *}$ & $0.037^{* * *}$ & $0.044^{* * *}$ \\
FD $\times(\ln y)^{2}$ & $(0.002)$ & $(0.002)$ & $(0.002)$ \\
& $0.509^{* * *}$ & $0.309^{* * *}$ & $0.488^{* * *}$ \\
$\ln y$ & $(0.021)$ & $(0.020)$ & $(0.023)$ \\
& $-0.020^{* * *}$ & $-0.008^{* * *}$ & $-0.018^{* * *}$ \\
$(\ln y)^{2}$ & $(0.001)$ & $(0.001)$ & $(0.001)$ \\
Per-unit Freight Charges $(\ln )$ & $0.567^{* * *}$ & $0.598^{* * *}$ & $0.564^{* * *}$ \\
& $(0.001)$ & $(0.001)$ & $(0.001)$ \\
Duty / Dutiable Value & $-1.196^{* * *}$ & $-1.089^{* * *}$ & $-1.186^{* * *}$ \\
Population $(\ln )$ & $(0.136)$ & $(0.048)$ & $(0.139)$ \\
& 0.000 & $-0.015^{* * *}$ & $0.005^{* * *}$ \\
& $(0.001)$ & $(0.001)$ & $(0.001)$ \\
\hline Observations & $1,274,264$ & $1,196,241$ & $1,189,332$ \\
$R^{2}$ & 0.88 & 0.88 & 0.88 \\
\hline
\end{tabular}

Notes: The measure of Financial Development (FD) is private credit over GDP. ln $y$ is the natural logarithm of GDP per capita. Per-unit Freight Charges is calculated by dividing import charges (the difference between FOB and CIF prices) by import quantity. All regressions include a constant term and product-year fixed effect. Robust standard errors clustered by exporter-product in parentheses. * significant at $10 \%$; ** significant at $5 \%$; *** significant at $1 \%$.

From Table 1, we can calculate if we indeed observe a non-linear effect of financial development on the price of exported products. First, note that the interaction term of FD and $(\ln y)^{2}$ is positive, while the interaction term of FD and $\ln y$ is negative. Thus, we can have the potential to find the U-shaped effect if the minimizer of the following quadratic function provides an interior income per capita:

$$
f(\ln y)=\beta_{3}(\ln y)^{2}+\beta_{2} \ln y .
$$


In addition, from Table 1 , by applying the formula $-\beta_{2} /\left(2 \beta_{3}\right)$, we can compute the GDP per capita that minimizes the quadratic function above: $\$ 3,505.76, \$ 5,187.74$ and $\$ 4,914.77$ for each column. Obviously, these values are greater than the minimum (\$108) and less than the maximum $(\$ 106,920)$. They are close to the per capita incomes of Costa Rica in 1997, Palau in 1992, and Malaysia in 2004, respectively. The World Bank classifies these countries as upper-middle income economies. ${ }^{14}$ This result confirms the non-linear effect of better access to external finance on the price of exported products.

The percentage of countries whose average GDP per capita over 1991-2007 is less than that minimizing the effect of financial development on the export price is $58 \%, 69 \%$ and $67 \%$ for each column of Table 1. Ideally, the median sample country should have an average GDP per capita that minimizes the effect of financial development on the price. As the figures above indicate, there has been a trend of a decreasing marginal effect of financial development on the export price in relatively low income countries. The rest of the countries with a relatively high income per capita tend to experience an increasing effect of financial development on the price. The empirical results above show that the data support the predictions from the model.

Figure 1 displays the extent of the marginal effect of financial development, based on the coefficients in column 1 of Table 1, over a varying range of the natural logarithm of per capita GDP in 1991 and 2007. This reflects the data used in the regression analysis. The results show that as financial systems improve, the marginal effect on export price is positive in countries with the highest and lowest per capita incomes and negative in middle income countries. The strongest negative effect is observed for the middle-income countries with an income per capita around $\$ 3,563$, which is a $2.7 \%$ decrease in export prices for every $10 \%$ increase in the measure of financial development (the ratio of private credit to GDP). The weakest negative effect - a $0-0.5 \%$ decrease in export prices for every $10 \%$ increase in financial development - is observed for low income countries with a per capita income

\footnotetext{
14 The GDP per capita (2014 US\$) is $\$ 648.1$ for the low income group, $\$ 2,032.8$ for the lower middle income group, $\$ 7,986.9$ for the upper middle income group, and $\$ 37,896.8$ for the high income group. Source: http://data. worldbank. org/country.
} 
Figure 1: Marginal effect of financial development on (log) export prices over a varying range of GDP per capita, with the 1991 and 2007 incomes
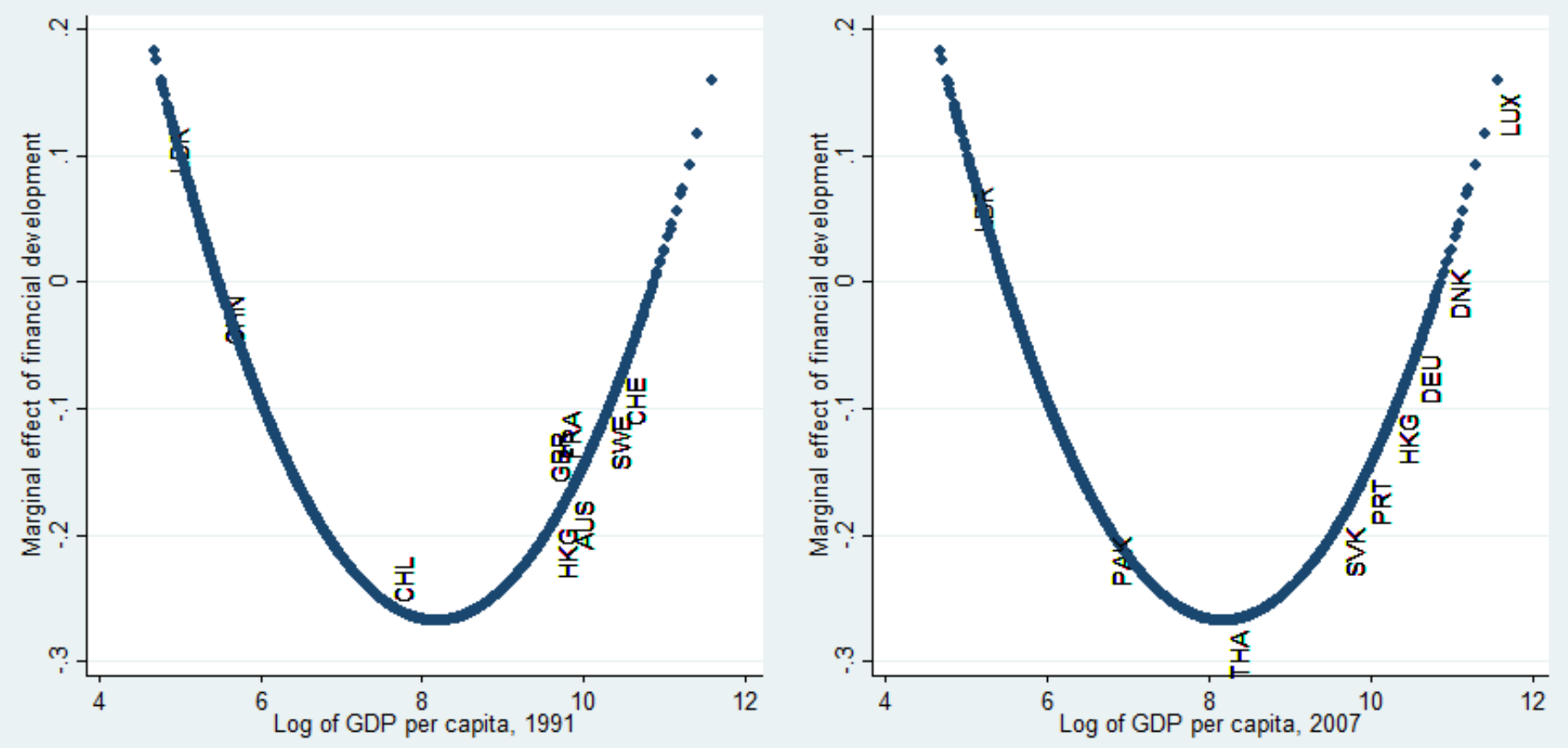

Notes: (Left) The countries listed on the figure are those with minimum (LBR: Liberia), 5 percentile (CHN: China), 25 percentile (CHL: Chile), 45 percentile (HKG: Hong Kong SAR, China), median (GBR: United Kingdom), 55 percentile (AUS: Australia), 75 percentile (FRA: France), 95 percentile (SWE: Sweden), and maximum (CHE: Switzerland) of the natural logarithm of GDP per capita in 1991.

(Right) The countries listed on the figure are those with minimum (LBR: Liberia), 5 percentile (PAK: Pakistan), 25 percentile (THA: Thailand), 45 percentile (SVK: Slovak Republic), median (PRT: Portugal), 55 percentile (HKG: Hong Kong SAR, China), 75 percentile (DEU: Germany), 95 percentile (DNK: Denmark), and maximum (LUX: Luxembourg) of the natural logarithm of GDP per capita in 2007.

between $\$ 241$ and $\$ 314$, and for rich countries with a per capita income between $\$ 40,403$ and $\$ 52,414$. Among all samples, the marginal effect of financial development appears to be positive for 4,807 lowest income observations (GDP per capita averaging \$207.65) and 8,267 highest income observations (GDP per capita averaging $\$ 60,835.28$ ), which account for approximately $1.03 \%$ of all observations. Although this proportion is small, the main point is that the marginal effect of financial development is not monotonic.

Table 2 displays the number of countries that experienced positive and negative effects 
Table 2: Number of countries which experienced positive and negative effects of financial development in 1991 and 2007

\begin{tabular}{llcc}
\hline \hline & & \multicolumn{2}{c}{ Year } \\
\cline { 3 - 4 } & & 1991 & 2007 \\
\hline \multirow{3}{*}{ Number of countries which } & High-Income & 0 & 6 \\
face a positive effect & Mid-Income & 1 & 0 \\
& Low-Income & 8 & 1 \\
\cline { 2 - 4 } & Total & 9 & 7 \\
\hline \multirow{2}{*}{ Number of countries which } & High-Income & 43 & 45 \\
face a negative effect & Mid-Income & 66 & 88 \\
& Low-Income & 15 & 22 \\
\cline { 2 - 4 } & Total & 124 & 155 \\
\hline Total number of countries & & 133 & 162 \\
\hline
\end{tabular}

of financial development in 1991 and 2007, and the numbers of low, middle, and high income countries in each case. In 1991, no high income countries experienced a positive effect of financial development, while only one middle income country and eight lowest income countries did. On the contrary, approximately $93 \%$ of countries experienced a negative effect of financial development in 1991, and more than half of these (53\%) were middle income countries. Interestingly, we find that a much higher proportion of high income countries than middle and low income countries experienced a positive effect of financial development in 2007. While the number and share of countries that experienced a positive effect of financial development decreased, the proportion of high income countries increased from $0 \%$ to $86 \%$. In 2007, $95.7 \%$ of countries experienced a negative marginal effect of financial development. The proportion of middle income countries among those that had a negative effect was about $57 \%$, which was much higher as compared to the high (29\%) and low (14\%) income countries.

We also estimate a model with the same specification as column 1 of Table 1 to show the impact of financial development for each HS 2-digit level industry group (see Table 3; for industry classification, see Table B.2.). ${ }^{15}$ There are nine industry groups that experienced the

\footnotetext{
15 The industry classification of the HS code is adopted from http://www.foreign-trade.com/reference/hscode.htm.
} 
U-shaped effect of improved financial constraints: (2) Chemicals and Allied Industries; (3) Foodstuffs; (5) Machinery/Electrical; (6) Metals; (7) Mineral Products; (8) Miscellaneous; (9) Plastics/Rubbers; (12) Textiles; and (15) Wood and Wood Products. Table 4 shows the ratio of the import value of a respective sector to total import value. The 9 industry groups above account for $69 \%$ of the total import value, and about $63 \%$ of them are differentiated goods. 


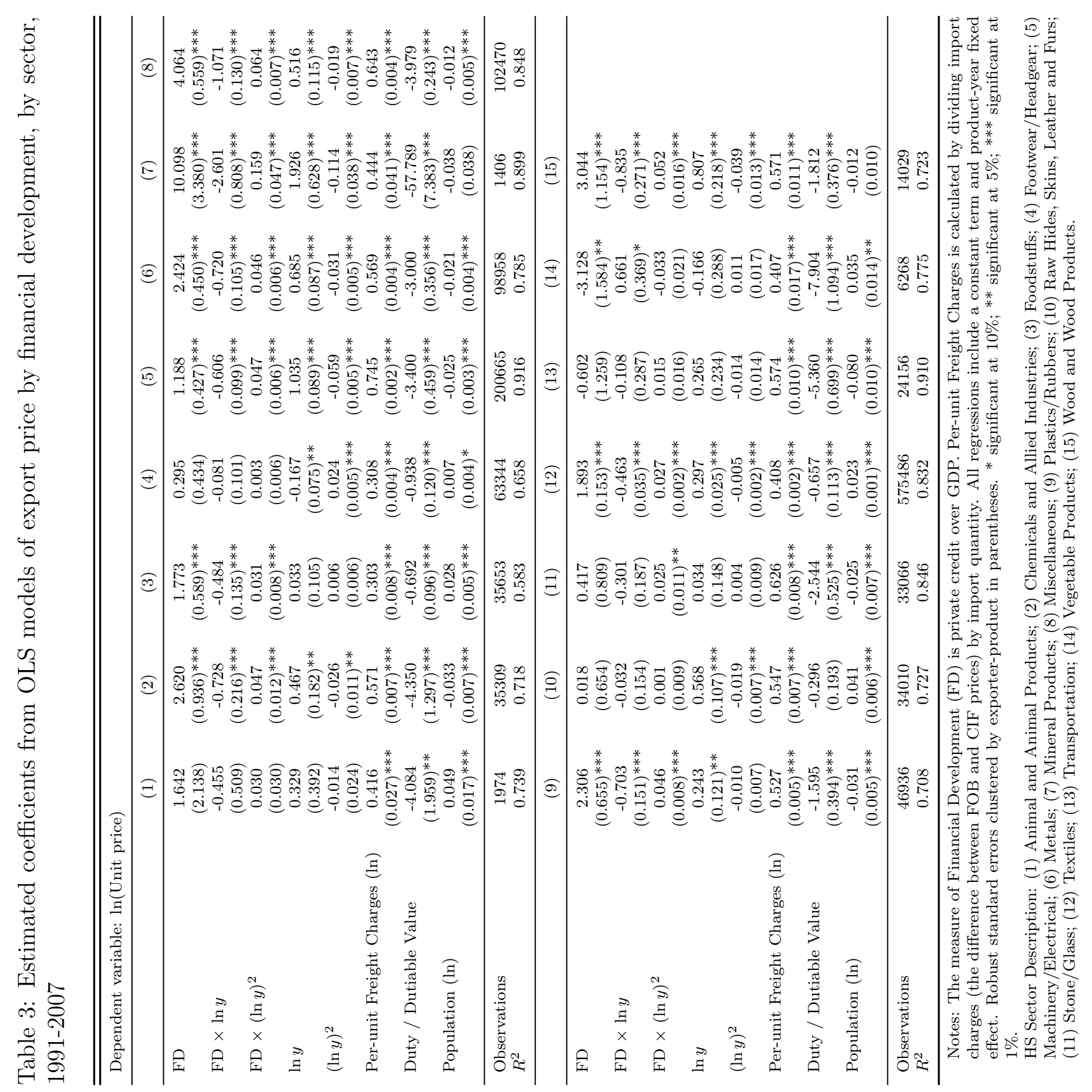


Table 4: Fraction of total import value for differentiated and homogeneous goods in each industry group, 1991-2007

\begin{tabular}{lcccccccc}
\hline \hline & $(1)$ & $(2)$ & $(3)$ & $(4)$ & $(5)$ & $(6)$ & $(7)$ & $(8)$ \\
\hline Total & 0.0091 & 0.0314 & 0.0196 & 0.0261 & 0.1912 & 0.0491 & 0.1515 & 0.1025 \\
Differentiated & 0.0001 & 0.0090 & 0.0057 & 0.0258 & 0.1905 & 0.0253 & 0.0001 & 0.0809 \\
Homogeneous & 0.0089 & 0.0187 & 0.0136 & & & 0.0205 & 0.0003 & \\
\hline & $(9)$ & $(10)$ & $(11)$ & $(12)$ & $(13)$ & $(14)$ & $(15)$ & \\
\hline Total & 0.0286 & 0.0103 & 0.0122 & 0.1004 & 0.2379 & 0.0090 & 0.0109 & \\
Differentiated & 0.0194 & 0.0091 & 0.0095 & 0.0945 & 0.2368 & 0.0012 & 0.0035 & \\
Homogeneous & 0.0083 & & 0.0006 & 0.0042 & & 0.0066 & 0.0031 & \\
\hline
\end{tabular}

HS Sector Description: (1) Animal and Animal Products; (2) Chemicals and Allied Industries; (3) Foodstuffs; (4) Footwear/Headgear; (5) Machinery/Electrical; (6) Metals; (7) Mineral Products; (8) Miscellaneous; (9) Plastics/Rubbers; (10) Raw Hides, Skins, Leather and Furs; (11) Stone/Glass; (12) Textiles; (13) Transportation; (14) Vegetable Products; (15) Wood and Wood Products.

\section{Conclusion}

This paper demonstrates the relationship between financial development and export prices, and, more importantly, explains how the level of economic development of an exporting country influences the impact of the financial development. Our theoretical predictions can be summarized as follows: (i) financial development has an ambiguous effect on export prices, since it not only reduces the production costs for a given quality level but also induces costly quality upgrading. Less financially constrained exporters charge lower prices than the more constrained firms do when the cost-adjustment effect of financial development dominates the quality-adjustment effect, and (ii) the marginal effect of financial development is the lowest for countries with a medium level of labor productivity, compared with those with a low or high level.

Using data on product-level U.S. imports obtained from the U.S. Census Bureau, we provide new evidence not only of the effect of financial development on export prices but also of the trend of the effect across countries with different per capita income levels. We find that financial development tends to reduce the price of exported products. More interestingly, we show that the negative marginal effect of financial development on export prices can be mitigated in the countries with the highest and lowest incomes. The proportion of middle 
income countries among those that experience a negative effect is twice and four times as much as that of high and low income countries, respectively. The main results are robust and survive the inclusion of various control variables and the exclusion of countries neighboring the U.S. (Canada and Mexico) and the largest developing countries (China and India). 


\section{REFERENCES}

Akbari, A. H. (1996). Provincial Income Disparities in Canada: Does the Quality of Education Matter? Canadian Journal of Economics, pages 337-339.

Altonji, J. G. and Blank, R. M. (1999). Race and Gender in the Labor Market. Handbook of Labor Economics, 3:3143-3259.

Antoniades, A. (2015). Heterogeneous Firms, Quality, and Trade. Journal of International Economics, 95(2):263-273.

Balassa, B. (1978). Exports and Economic Growth: Further Evidence. Journal of Development Economics, 5(2):181-189.

Baldwin, R. and Harrigan, J. (2011). Zeros, Quality, and Space: Trade Theory and Trade Evidence. American Economic Journal: Microeconomics, 3(2):60-88.

Beck, T. (2002). Financial Development and International Trade: Is There a Link? Journal of International Economics, 57(1):107-131.

Beck, T. (2003). Financial Dependence and International Trade. Review of International Economics, 11(2):296-316.

Berthou, A. (2010). The Distorted Effect of Financial Development on International Trade Flows. Technical report, CEPII Research Center.

Bils, M. and Klenow, P. J. (2001). Quantifying Quality Growth. American Economic Review, pages $1006-1030$.

Brooks, E. L. (2006). Why Don't Firms Export More? Product Quality and Colombian Plants. Journal of Development Economics, 80(1):160-178.

Ciani, A. and Bartoli, F. (2014). Export Quality Upgrading Under Credit Constraints. Technical report, Bocconi University. 
Coulombe, S., Grenier, G., and Nadeau, S. (2014). Quality of Work Experience and Economic Development: Estimates Using Canadian Immigrant Data. Journal of Human Capital, $8(3): 199-234$.

Crozet, M., Head, K., and Mayer, T. (2012). Quality Sorting and Trade: Firm-level Evidence for French Wine. Review of Economic Studies, 79(2):609-644.

Fajgelbaum, P., Grossman, G. M., and Helpman, E. (2011). Income Distribution, Product Quality, and International Trade. Journal of Political Economy, 119(4):721-765.

Fan, H., Lai, E. L.-C., and Li, Y. A. (2015). Credit Constraints, Quality, and Export Prices: Theory and Evidence from China. Journal of Comparative Economics, 43(2):390-416.

Feder, G. (1983). On Exports and Economic Growth. Journal of Development Economics, 12(1):59-73.

Flam, H. and Helpman, E. (1987). Vertical Product Differentiation and North-South Trade. American Economic Review, pages 810-822.

Galor, O. and Zeira, J. (1993). Income Distribution and Macroeconomics. Review of Economic Studies, 60(1):35-52.

Haltiwanger, J. C., Lane, J. I., and Spletzer, J. R. (2007). Wages, Productivity, and the Dynamic Interaction of Businesses and Workers. Labour Economics, 14(3):575-602.

Hummels, D. and Klenow, P. J. (2005). The Variety and Quality of a Nation's Exports. American Economic Review, pages 704-723.

Iacovone, L. and Javorcik, B. (2008). Shipping the Good Tequila Out: Investment, Domestic Unit Values and Entry of Multi-product Plants into Export Markets.

Jovanovic, B. (1984). Matching, Turnover, and Unemployment. Journal of Political Economy, pages 108-122. 
Kavoussi, R. M. (1984). Export Expansion and Economic Growth: Further Empirical Evidence. Journal of Development Economics, 14(1):241-250.

Khandelwal, A. (2010). The Long and Short (of) Quality Ladders. Review of Economic Studies, 77(4):1450-1476.

Krueger, A. O. (1980). Trade Policy as an Input to Development. American Economic Review, pages 288-292.

Manova, K. (2013). Credit Constraints, Heterogeneous Firms, and International Trade. Review of Economic Studies, 80(2):711-744.

Manova, K. and Zhang, Z. (2012). Export Prices Across Firms and Destinations. Quarterly Journal of Economics, 127:379-436.

Moscarini, G. (2005). Job Matching and the Wage Distribution. Econometrica, 73(2):481516.

Moschos, D. (1989). Export Expansion, Growth and the Level of Economic Development: An Empirical Analysis. Journal of Development Economics, 30(1):93-102.

Phillips, G. and Sertsios, G. (2013). How Do Firm Financial Conditions Affect Product Quality and Pricing? Management Science, 59(8):1764-1782.

Pierce, J. R. and Schott, P. K. (2012). Concording US Harmonized System Codes over Time. Journal of Official Statistics, 28(1):53-68.

Pissarides, C. A. (1990). Equilibrium Unemployment Theory. MIT press.

Rauch, J. E. (1999). Networks versus Markets in International Trade. Journal of International Economics, 48(1):7-35.

Rogerson, R., Shimer, R., and Wright, R. (2005). Search-Theoretic Models of the Labor Market: A Survey. Journal of Economic Literature, 43(4):959-988. 
Schott, P. K. (2004). Across-Product versus Within-Product Specialization in International Trade. Quarterly Journal of Economics, pages 647-678.

Secchi, A., Tamagni, F., and Tomasi, C. (2014). Export Price Adjustments under Financial Constraints.

Svaleryd, H. and Vlachos, J. (2005). Financial Markets, the Pattern of Industrial Specialization and Comparative Advantage: Evidence from OECD Countries. European Economic Review, 49(1):113-144.

Verhoogen, E. A. (2008). Trade, Quality Upgrading, and Wage Inequality in the Mexican Manufacturing Sector. Quarterly Journal of Economics, 123(2):489-530. 


\section{Appendix A. Proofs}

A.1 Proof of Proposition 1 We can derive from Equation (6):

$$
\frac{\partial q^{*}}{\partial \rho}=-\frac{\alpha^{k}}{(1-\alpha)} \frac{1}{1+r} \frac{\partial r}{\partial \rho}\left(\eta \lambda_{d} \delta_{d}^{\alpha} \theta^{\alpha}\right)^{1 /(1-\alpha)}>0
$$

A.2 Proof of Proposition 2 We can derive from Equation (7):

$$
\frac{\partial p\left(q^{\prime}\right)}{\partial \rho}=\frac{\partial r}{\partial \rho} \underline{w}<0
$$

A.3 Proof of Proposition 3 We first show the decreasing marginal product of labor productivity in quality upgrading and the linear relationship between labor productivity and wages. Given the positive relationship between the quality of worker and labor productivity, we compute the marginal product of the quality of the worker in the production function of quality. That is,

$$
\frac{d q}{d e_{d}}=\lambda_{d}\left(k_{d}\right)^{\alpha^{k}} \alpha^{l}\left(e_{d}\right)^{\alpha^{l}-1}
$$

which are positive and decrease as the quality of each worker is incrementally increased, while keeping other factors constant, i.e.,

$$
\frac{d^{2} q}{d e_{d}^{2}}=\lambda_{d}\left(k_{d}\right)^{\alpha^{k}} \alpha^{l}\left(\alpha^{l}-1\right)\left(e_{d}\right)^{\alpha^{l}-2}<0
$$

It implies that quality upgrading is relatively cheap for firms in countries with very low levels of workers' skills (or labor productivity), but it becomes more expensive as labor productivity increases. 
On the other hand, wages increase in labor productivity:

$$
\frac{d w_{d}}{d u_{d}}=\gamma_{1}
$$

As a result, firms in countries with the lowest labor productivity have stronger incentives to increase quality as wages are relatively low compared to the marginal product of labor in quality upgrading. It is more pronounced when external capital is cheaper to borrow. Hence, the quality-adjustment effect is stronger than the cost-adjustment effect in the countries with the lowest levels of labor productivity. As labor productivity increases, the incentive to improve quality due to financial development decreases and therefore the qualityadjustment effect becomes relatively weaker than cost-adjustment effect. Since the marginal cost increases in quality, quality upgrading is more costly in countries with higher labor productivity. Hence, even an incremental increase in quality results in tremendous increase in the cost of quality upgrading and the corresponding increase in prices, which implies that the quality-adjustment effect is stronger compared to the cost-adjustment effect.

This can be shown in the following way.

$$
\begin{aligned}
\frac{\partial^{2} p^{*}}{\partial \rho \partial u_{d}} & =\frac{\partial r}{\partial \rho} \frac{d \underline{w}}{d u_{d}}+\alpha \delta_{d} \theta \frac{\partial^{2} q^{*}}{\partial \rho \partial u_{d}} \\
& =\left[\gamma_{1}-\frac{\alpha}{(1-\alpha)^{2}} \delta_{d} \theta\left(\eta \delta_{d}^{\alpha} \theta^{\alpha}\right)^{\frac{1}{1-\alpha}} \lambda_{d}^{\frac{\alpha}{1-\alpha}} \gamma_{1}^{\lambda} \frac{\alpha^{k}}{1+r}\right] \frac{\partial r}{\partial \rho}
\end{aligned}
$$

is positive if

$$
\frac{1}{\gamma_{1}^{\lambda}}\left[\frac{\gamma_{1}}{\frac{\alpha}{(1-\alpha)^{2}} \delta_{d} \theta\left(\eta \delta_{d}^{\alpha} \theta^{\alpha}\right)^{\frac{1}{1-\alpha}} \gamma_{1}^{\lambda} \frac{\alpha^{k}}{1+r}}\right]^{\frac{1-\alpha}{\alpha}}-\frac{\gamma_{0}^{\lambda}}{\gamma_{1}^{\lambda}}<u_{d}
$$

and negative if

$$
\frac{1}{\gamma_{1}^{\lambda}}\left[\frac{\gamma_{1}}{\frac{\alpha}{(1-\alpha)^{2}} \delta_{d} \theta\left(\eta \delta_{d}^{\alpha} \theta^{\alpha}\right)^{\frac{1}{1-\alpha}} \gamma_{1}^{\lambda} \frac{\alpha^{k}}{1+r}}\right]^{\frac{1-\alpha}{\alpha}}-\frac{\gamma_{0}^{\lambda}}{\gamma_{1}^{\lambda}}>u_{d}
$$


Positive and Negative Effects of Financial Development on Export Prices

This shows that $\frac{\partial p^{*}}{\partial \rho}$ has a $\mathrm{U}$ shape with the lowest value at

$$
u_{d}=\frac{1}{\gamma_{1}^{\lambda}}\left[\frac{\gamma_{1}}{\frac{\alpha}{(1-\alpha)^{2}} \delta_{d} \theta\left(\eta \delta_{d}^{\alpha} \theta^{\alpha}\right)^{\frac{1}{1-\alpha}} \gamma_{1}^{\lambda} \frac{\alpha^{k}}{1+r}}\right]^{\frac{1-\alpha}{\alpha}}-\frac{\gamma_{0}^{\lambda}}{\gamma_{1}^{\lambda}} .
$$


Appendix B. Data

Table B.1: List of countries with GDP per capita data

\begin{tabular}{|c|c|c|c|c|c|c|c|}
\hline \multirow{2}{*}{$\begin{array}{l}\text { ISO3 } \\
\text { country } \\
\text { code }\end{array}$} & \multirow[t]{2}{*}{ Country name } & \multicolumn{2}{|c|}{$\begin{array}{l}\text { GDP per capita } \\
\text { (current US\$) }\end{array}$} & \multirow{2}{*}{$\begin{array}{c}\text { ISO3 } \\
\text { country } \\
\text { code }\end{array}$} & \multirow[t]{2}{*}{ Country name } & \multicolumn{2}{|c|}{$\begin{array}{l}\text { GDP per capita } \\
\text { (current US\$) }\end{array}$} \\
\hline & & 1991 & 2007 & & & 1991 & 2007 \\
\hline AFG & Afghanistan & & 373.591 & KGZ & Kyrgyz Republic & & 721.769 \\
\hline AGO & Angola & & 3412.72 & KHM & Cambodia & & 628.427 \\
\hline ALB & Albania & & 3380.89 & KNA & St. Kitts and Nevis & 4013.13 & 13586.4 \\
\hline ARE & United Arab Emirates & 27018.9 & 44529 & KOR & Korea, Rep. & 7122.7 & 21590.1 \\
\hline ARG & Argentina & 5736.02 & 6630.05 & KWT & Kuwait & 5505.94 & 44902.3 \\
\hline ARM & Armenia & & 3079.14 & LAO & Lao PDR & 235.264 & 702.27 \\
\hline ATG & Antigua and Barbuda & 6575.48 & 15276.1 & LBN & Lebanon & 1617.27 & 6052.62 \\
\hline AUS & Australia & 18870.3 & 40470.1 & LBR & Liberia & 168.437 & 209.814 \\
\hline AUT & Austria & 22180.7 & 45181.5 & LCA & St. Lucia & 3078.43 & 6612.78 \\
\hline AZE & Azerbaijan & & 3851.33 & LKA & Sri Lanka & 521.246 & 1614.36 \\
\hline BDI & Burundi & 203.034 & & LSO & Lesotho & 373.959 & 816.783 \\
\hline BEL & Belgium & 20785.5 & 43255.4 & LTU & Lithuania & & 11584.2 \\
\hline BEN & Benin & 383.295 & 632.361 & LUX & Luxembourg & 35439.3 & 106920 \\
\hline BFA & Burkina Faso & 346.41 & 474.59 & LVA & Latvia & & 12638.1 \\
\hline BGD & Bangladesh & 281.599 & 467.136 & MAC & Macao SAR, China & 9377.8 & 36606.8 \\
\hline BGR & Bulgaria & 1267.73 & 5498.04 & MAR & Morocco & 1098.01 & 2416.26 \\
\hline BHR & Bahrain & 9057.72 & 17894.2 & MDA & Moldova & & 1230.81 \\
\hline BHS & Bahamas, The & 11915.5 & 24321.1 & MDG & Madagascar & 222.986 & 379.066 \\
\hline BIH & Bosnia and Herzegovina & & 3949.84 & MDV & Maldives & 1101.39 & \\
\hline BLR & Belarus & & 4735.95 & MEX & Mexico & 3577.81 & 9124.27 \\
\hline BLZ & Belize & 2323.9 & 4461.11 & MKD & Macedonia, FYR & & 3891.9 \\
\hline BOL & Bolivia & 768.07 & 1355.88 & MLI & Mali & 297.995 & 561.496 \\
\hline BRA & Brazil & 2677.15 & 7194.08 & MLT & Malta & 7688.03 & 18369 \\
\hline BRB & Barbados & 6484.74 & 12339.8 & MNE & Montenegro & & 5938.58 \\
\hline BRN & Brunei Darussalam & & 32108.9 & MNG & Mongolia & 1072.63 & 1631.9 \\
\hline BTN & Bhutan & 467.458 & 1760.6 & MOZ & Mozambique & 197.858 & 362.432 \\
\hline BWA & Botswana & 2767.88 & 5711.75 & MRT & Mauritania & & 1008.02 \\
\hline $\mathrm{CAF}$ & Central African Republic & & 413.285 & MUS & Mauritius & 2669.33 & 6182.2 \\
\hline CAN & Canada & 21234.4 & 43248.5 & MWI & Malawi & 228.168 & \\
\hline $\mathrm{CHE}$ & Switzerland & 36309.5 & 59663.8 & MYS & Malaysia & 2626.08 & 7218.4 \\
\hline CHL & Chile & 2706.81 & 10383.5 & NAM & Namibia & 1699.89 & 4234.93 \\
\hline $\mathrm{CHN}$ & China & 329.749 & 2651.26 & NER & Niger & 290.851 & 302.266 \\
\hline CIV & Cote d'Ivoire & 837.395 & 1102.88 & NGA & Nigeria & 278.465 & 1127.28 \\
\hline CMR & Cameroon & 1000.32 & 1069.86 & $\mathrm{NIC}$ & Nicaragua & 351.369 & 1330.82 \\
\hline COG & Congo, Rep. & & 2233.31 & NLD & Netherlands & 20130.7 & 47770.8 \\
\hline COL & Colombia & 1214.45 & 4661.21 & NOR & Norway & 28077.2 & \\
\hline $\mathrm{COM}$ & Comoros & 583.55 & 734.823 & NPL & Nepal & 211.179 & 397.904 \\
\hline CPV & Cape Verde & 889.293 & 2752.06 & NZL & New Zealand & 11967 & 31895.7 \\
\hline CRI & Costa Rica & 2269.52 & 5897.5 & OMN & Oman & 6016.59 & 16305.6 \\
\hline CYP & Cyprus & 9696.1 & 27860.3 & PAK & Pakistan & 397.902 & 873.377 \\
\hline CZE & Czech Republic & & 17467.4 & PAN & Panama & 2300.9 & 5669.87 \\
\hline DEU & Germany & 22603.6 & 40403 & PER & Peru & 1555.12 & 3785.35 \\
\hline DJI & Djibouti & 754.865 & 1061.64 & PHL & Philippines & 715.502 & 1680.55 \\
\hline DMA & Dominica & 2546.78 & 5829.34 & PNG & Papua New Guinea & 888.675 & 989.319 \\
\hline DNK & Denmark & 26520.4 & 57021.2 & POL & Poland & 2187.15 & 11157.3 \\
\hline DOM & Dominican Republic & 1315.46 & 4287.8 & PRT & Portugal & 8832.69 & 21845.2 \\
\hline DZA & Algeria & 1699.86 & 3869.37 & PRY & Paraguay & 1601.79 & 2259.08 \\
\hline ECU & Ecuador & 1639.69 & 3574.88 & QAT & Qatar & 14189 & 69023.7 \\
\hline EGY & Egypt, Arab Rep. & 644.226 & 1757.76 & RUS & Russian Federation & & 9146.42 \\
\hline ERI & Eritrea & & 252.978 & RWA & Rwanda & 274.117 & \\
\hline ESP & Spain & 14391.6 & 32118.1 & SAU & Saudi Arabia & 7845.68 & 16048.6 \\
\hline
\end{tabular}


Table B.1 (Continued)

\begin{tabular}{|c|c|c|c|c|c|c|c|}
\hline EST & Estonia & & 16392.7 & SDN & Sudan & 428.77 & \\
\hline ETH & Ethiopia & 268.605 & 243.12 & SEN & Senegal & 724.841 & 950.842 \\
\hline FIN & Finland & 24991.5 & 46538.2 & SGP & Singapore & 13736.8 & 36766.3 \\
\hline FJI & Fiji & 1882.25 & 4075.99 & SLB & Solomon Islands & 998.725 & \\
\hline FRA & France & 21268.2 & 40341.9 & SLE & Sierra Leone & 192.433 & 398.438 \\
\hline FSM & Micronesia, Fed. Sts. & & 2434.81 & SLV & El Salvador & 978.933 & 3283.53 \\
\hline GAB & Gabon & 5555.48 & 7994.3 & SRB & Serbia & & 5276.93 \\
\hline GBR & United Kingdom & 18532.1 & 46330.2 & STP & Sao Tome and Principe & & 882.914 \\
\hline GEO & Georgia & & 2317.99 & SUR & Suriname & 1085.78 & 5753.18 \\
\hline GHA & Ghana & 438.949 & 1099.09 & SVK & Slovak Republic & & 15583.4 \\
\hline GIN & Guinea & 474.654 & 418.965 & SVN & Slovenia & & 23441 \\
\hline GMB & Gambia, The & 727.042 & 522.34 & SWE & Sweden & 29912.2 & 50558.4 \\
\hline GNB & Guinea-Bissau & 247.09 & & SWZ & Swaziland & 1303.06 & 2690.65 \\
\hline GRC & Greece & 9775.54 & 27288.3 & SYC & Seychelles & 5290.65 & 12155.7 \\
\hline GRD & Grenada & 2504.49 & 7324.19 & SYR & Syrian Arab Republic & 1012.76 & 2065.54 \\
\hline GTM & Guatemala & 1033.79 & 2561.44 & TCD & Chad & 305.595 & \\
\hline GUY & Guyana & 465.543 & 2258.98 & TGO & Togo & 412.144 & 432.484 \\
\hline HKG & Hong Kong SAR, China & 15465.9 & 30594 & THA & Thailand & 1717.86 & 3737.72 \\
\hline HND & Honduras & 608.607 & 1721.55 & TJK & Tajikistan & & 523.061 \\
\hline HRV & Croatia & & 13376 & TON & Tonga & 1386.9 & 2943.27 \\
\hline HTI & Haiti & 479.163 & 627.65 & TTO & Trinidad and Tobago & 4360.35 & 16591.4 \\
\hline HUN & Hungary & 3287.89 & 13534.7 & TUN & Tunisia & 1571.83 & 3799.35 \\
\hline IDN & Indonesia & 705.048 & 1871.29 & TUR & Turkey & 2750.64 & 9312.05 \\
\hline IND & India & 310.084 & 1068.68 & TZA & Tanzania & 193.575 & 421.3 \\
\hline IRL & Ireland & 13837.2 & 59286.6 & UGA & Uganda & & 387.781 \\
\hline IRN & Iran, Islamic Rep. & & 3983.58 & UKR & Ukraine & & 3068.61 \\
\hline IRQ & Iraq & & 3091.02 & URY & Uruguay & 3578.04 & 7012.54 \\
\hline ISL & Iceland & 26405.9 & 65566.3 & $\mathrm{VCT}$ & St. Vincent and the Grenadines & 1970.97 & 6273.09 \\
\hline ISR & Israel & 11956 & 23274.3 & VEN & Venezuela, RB & 2558.72 & 8329.64 \\
\hline ITA & Italy & 21154.8 & 35826 & VNM & Vietnam & & 843.204 \\
\hline JAM & Jamaica & 1706.62 & 4791.11 & WSM & Samoa & & 2693.79 \\
\hline JOR & Jordan & 1182.89 & 3022.54 & YEM & Yemen, Rep. & & 1019.54 \\
\hline JPN & Japan & 28540.8 & 34094.9 & $\mathrm{ZAF}$ & South Africa & & 5930.13 \\
\hline KAZ & Kazakhstan & & 6771.42 & ZMB & Zambia & 420.091 & 953.079 \\
\hline KEN & Kenya & 336.323 & 721.459 & ZWE & Zimbabwe & 805.128 & \\
\hline
\end{tabular}


Table B.2: Industry classification

\begin{tabular}{cl}
\hline \hline HS code & \multicolumn{1}{c}{ Name of industry } \\
\hline $01-05$ & Animal and Animal Products \\
$06-15$ & Vegetable Products \\
$16-24$ & Foodstuffs \\
$25-27$ & Mineral Products \\
$28-38$ & Chemicals and Allied Industries \\
$39-40$ & Plastics / Rubbers \\
$41-43$ & Raw Hides, Skins, Leather, and Furs \\
$44-49$ & Wood and Wood Products \\
$50-63$ & Textiles \\
$64-67$ & Footwear / Headgear \\
$68-71$ & Stone / Glass \\
$72-83$ & Metals \\
$84-85$ & Machinery / Electrical \\
$86-89$ & Transportation \\
$90-97$ & Miscellaneous \\
$98-99$ & Service \\
\hline
\end{tabular}

Source: http://www.foreign-trade.com/ reference/hscode.htm 